\title{
Work-related stress and musculoskeletal complaints of orchestra musicians*
}

\author{
Estresse relacionado ao trabalho e queixas musculoesqueléticas em músicos de orquestra
}

Érico Felden Pereira ${ }^{1}$, Fausto Kothe ${ }^{1}$, Fernanda Tolentino de Souza Bleyer ${ }^{1}$, Clarissa Stefani Teixeira²

${ }^{*}$ Received from the Center of Health and Sports Sciences, University of the State of Santa Catarina, Florianópolis, SC, Brazil.

\section{ABSTRACT}

BACKGROUND AND OBJECTIVES: Professional musicians are commonly affected by musculoskeletal discomfort. Understanding the association of such affections with psychic health may contribute to promote the health of such professionals. So, this study aimed at investigating associations between work-related stress and musculoskeletal complaints of orchestra musicians.

METHODS: This study was developed with 22 orchestra musicians. Evaluation of the frequency of musculoskeletal complaints in different body regions and of work-related stress was carried out according to Theorell and Karasek's demand-control model. RESULTS: Most musculoskeletal complaints were on neck, left hemi-body and back. Forty one percent of musicians had perception of active work, with high demands (81\%), high intellectual judgment (95.4\%) and authority over decisions (72.7\%). Musicians in general had positive perception of social support. Workers with work perception with major stress and active had most frequent complaints. Factors were presented with questions which may be allocated for future ergonomic interventions.

CONCLUSION: A trend to more frequent muscle complaints of workers with work perception with higher demands was observed. Keywords: Human development, Mental health, Musculoskeletal pain, Psychological stress, Worker's health.

\section{RESUMO}

JUSTIFICATIVA E OBJETIVOS: Músicos profissionais são comumentemente acometidos por desconfortos musculoesqueléticos. $\mathrm{O}$ conhecimento da associação desses acometimentos com a

1. University of the State of Santa Catarina, Florianópolis, SC, Brazil.

2. Educational Society of Santa Catarina, Florianópolis, SC, Brazil.

Submitted in February 07, 2014.

Accepted for publication in May 05, 2014.

Conflict of interests: none.

Correspondence to:

Érico Felden Pereira

Rua Pascoal Simone, 358 - Coqueiros

88080-350 Florianópolis, SC, Brasil.

E-mail: ericofelden@gmail.com

(C) Sociedade Brasileira para o Estudo da Dor saúde psíquica pode contribuir para a promoção da saúde desses profissionais. Assim, este estudo teve como objetivo investigar as associaçóes entre estresse relacionado ao trabalho e queixas musculoesqueléticas em músicos de orquestra.

RESULTADOS: As maiores queixas musculoesqueléticas foram nas regióes do pescoço, hemi-corpo esquerdo e costas. Quarenta e um por cento dos músicos apresentaram percepção de trabalho ativo, com altas demandas (81\%), alto controle nas dimensôes de discernimento intelectual $(95,4 \%)$ e autoridade sobre decisóes (72,7\%). Os músicos, no geral, apresentaram percepção positiva na análise de apoio social. Trabalhadores com percepção de trabalho com alto desgaste e ativo apresentaram maiores frequências de queixas. Foram apresentados fatores com questóes que podem ser alocadas para futuras medidas de intervenção em ergonomia. CONCLUSÃO: Uma tendência de maiores frequências de queixas musculares nos trabalhadores com percepção de trabalho com maiores demandas foi verificada.

Descritores: Desenvolvimento humano, Dor musculoesquelética, Estresse psicológico, Saúde do trabalhador, Saúde mental.

\section{INTRODUCTION}

Musicians are a group especially exposed to occupational risks. In addition to the need for long training periods which may generate musculoskeletal overloads, the profession, in many realities, is not valued considering the adequacy of labor laws, as well as compensation and benefits, including late payments, lack of formal contracts and health plans ${ }^{1-4}$. In addition to the evident physical overload and, very often, the need to live with pain, musicians, dancers, athletes and other performative professionals are considered at risk for higher levels of stress, cognitive hearing problems and sleep disorders $^{5-9}$.

Studying stress at work is an important issue for the discussion of workers' health and is related to a set of reactions developed by the body after being submitted to circumstances requiring adaptation efforts, and are a response to situations which threaten to break their balance. Stress is important for human beings' evolution, because it may lead to active learning and coping behavior; however, when adaptation mechanisms fail, stress may trigger highly severe events for people's health ${ }^{10}$.

Karasek and Theorell demand and control model is one of the most widely used to study occupational stress. In this model, 
perception of workers about work overloads is classified as a function of the combination of activities demands, workers' control and social support received at work. So, psychological demands are related to working pace, how much it is excessive and difficult to be carried out, as well as the amount of conflict in labor relations. Control over work is the decision amplitude or margin workers have with regard to two aspects: autonomy to make decisions about their own work, included the pace in which it is carried out, and the possibility of being creative, using their own skills and develop them, as well as acquiring new knowledge ${ }^{11,12}$.

The demand and control model is being used as scientific approach to understand different types of workers, such as nurs$e^{13}{ }^{13}$, policemen ${ }^{14}$, bank clerks ${ }^{15}$ and professors ${ }^{16}$, and shows that the combination of working demands and freedom to make decisions is critical for the wellbeing or illness of such workers. Notwithstanding the above, the literature, especially the Brazilian literature, is scarce in analyses of different musicians' problems, bringing the need for physical and psychic health investigations aiming at proposing ergonomic interventions in workplace and practices of such workers. Aiming at contributing to filling this gap, this study has investigated the frequency of musculoskeletal complaints of orchestra musicians, according to work-related stress, based on the demand and control theory.

\section{METHODS}

This study was carried out in an orchestra from the Southern region of Brazil, composed of 29 musicians. For analysis purposes, we considered the results of 22 musicians (17 males and 5 females), mean age of $26.55 \pm 11.33$ years, who agreed in participating in the study, have answered the questionnaires and have returned to researchers filled questionnaires and the Free and Informed Consent Term, according to Resolution 196/96 of the National Health Council. Studied musicians acted in three different suits (types of instruments): strings (violin, viola, cello and bass), woods (clarinet and transverse flute) and metals (trumpet and trombone). Mean practice with current instrument played in the orchestra was $7.82 \pm 10.33$ years. Musicians considered in this analysis carried out all their labor activities related to music.

Data were collected by means of a questionnaire subdivided in: a) sociodemographic questions; b) analysis of musculoskeletal complaints; and c) work-related stress analysis. Musicians have answered the questionnaire under supervision of authors/researchers.

Musculoskeletal complaints were analyzed by means of a body map questionnaire ${ }^{17,18}$, culturally adapted to the Portuguese language by de Barros and Alexandre ${ }^{19}$. Reliability indices of the tool vary from 0.88 to 1 , according to Kappa coefficient and good concurrent validity indices according to Pinheiro, Tróccoli and Carvalho analysis ${ }^{20}$. This is a self-applicable tool presenting a human figure for the identification of the presence of musculoskeletal complaints in the last seven days.

A complaint index was considered for each body region ${ }^{21}$ being subjects classified as without complaints and with complaints in the trunk and upper limbs. Musculoskeletal complaints evaluated by this tool refer to pain, discomfort, tingling or numbness ${ }^{19}$.

A Job Stress Scale translated and validated for Brazil by Alves et al. ${ }^{22}$ was used to evaluate stress. The questionnaire has 17 questions which are checked considering a Likert scale (1-4) and deal with situations potentially causing stress to workers with regard to their jobs. The tool considers three dimensions: - Demand at work: psychological pressures, be them quantitative such as time and speed to perform the job, or qualitative, as conflicts between contradictory demands;

- Control at work: possibility of workers using their intellectual skills to perform the job, as well as having enough authority to make decisions on how to perform it;

- Social support: related to relations with colleagues and bosses. The combination of demand and control analyses allows the classification of work-related stress perception in four quadrants, according to figure 1 .

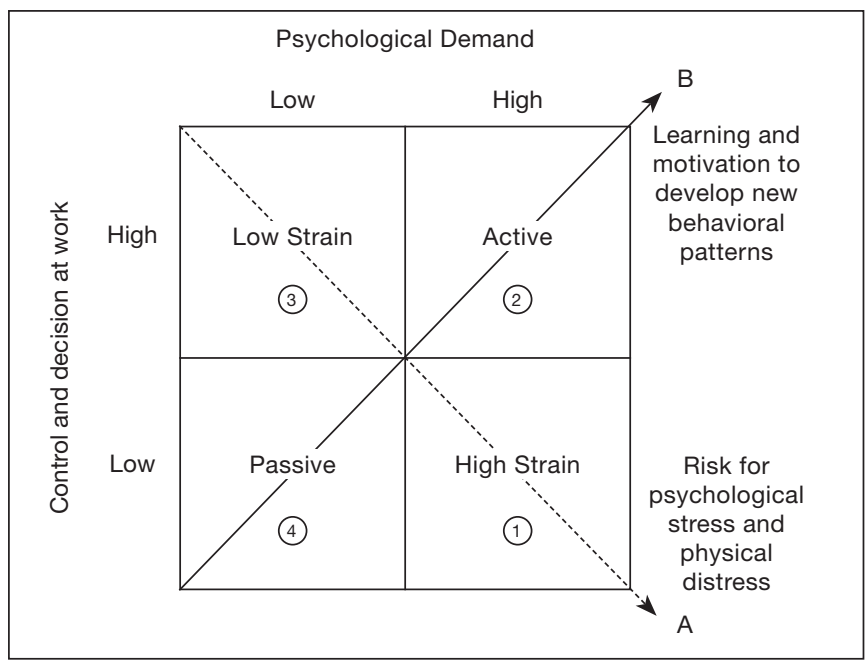

Figure 1. Demand-control model ${ }^{12}$

According to Alves et al. ${ }^{22}$, the test-retest reliability study has shown intra-class correlation coefficients for the dimensions "demand", "control" and "social support" of $0.88,0.87$ and 0.85 , respectively, being that for the same dimensions, internal consistency estimates (Cronbach's Alpha) were, respectively, $0.79,0.67$ and 0.85 .

Questions scores were allocated according to the answers of each subject in the four demand and control quadrants. Medians observed for each dimension were used to identify indicators of high and low demand for classification in the quadrants. Frequencies of general demand, control and social support indices were calculated considering the midpoint between maximum and minimum possible scores for each dimension.

Factorial analysis for major components was carried out to establish groups related to the 17 work-related stress questions, considering factors with self-scores above 1. "Varimax normalized" orthogonal rotation was used to calculate factors, 
with the purpose of minimizing the relation among factors. Questions with module of $\mathrm{p}>0.7$ were considered significant for these factors.

This study was approved by the Ethics Committee for Research with Human Beings, Federal University of Santa Catarina, under protocol 940/2010.

\section{RESULTS}

Higher frequencies of the presence of musculoskeletal complaints were neck, back and left hemi-body, specifically neck, left shoulder, upper back, left wrist, left hand and left arm (Table 1). Most musicians (41\%) had perception of active work and $31.8 \%$ of passive work (Figure 2 ). Considering the midpoint between minimum and maximum possible scores for each work-related stress dimension, a larger number of musicians $(81.8 \%)$ had perception of high demand of the profession.

With regard to control, most musicians (95.4\%) have perceived their professional activity as of high control with regard

Table 1. Frequencies of analyzed musculoskeletal complaints

\begin{tabular}{lc}
\hline Body region & $\begin{array}{c}\text { Frequency of musculoske- } \\
\text { letal complaints (\%) }\end{array}$ \\
\hline Neck & 54.5 \\
Left shoulder & 50.0 \\
Right shoulder & 22.7 \\
Left arm & 31.8 \\
Right arm & 13.6 \\
Left elbow & 9.1 \\
Right elbow & 9.1 \\
Left forearm & 18.2 \\
Right forearm & 13.6 \\
Left wrist & 36.4 \\
Right wrist & 22.7 \\
Left hand & 36.4 \\
Right hand & 27.3 \\
Upper back & 40.9 \\
Paravertebral region & 27.3 \\
Lumbar region & 27.3 \\
\hline
\end{tabular}

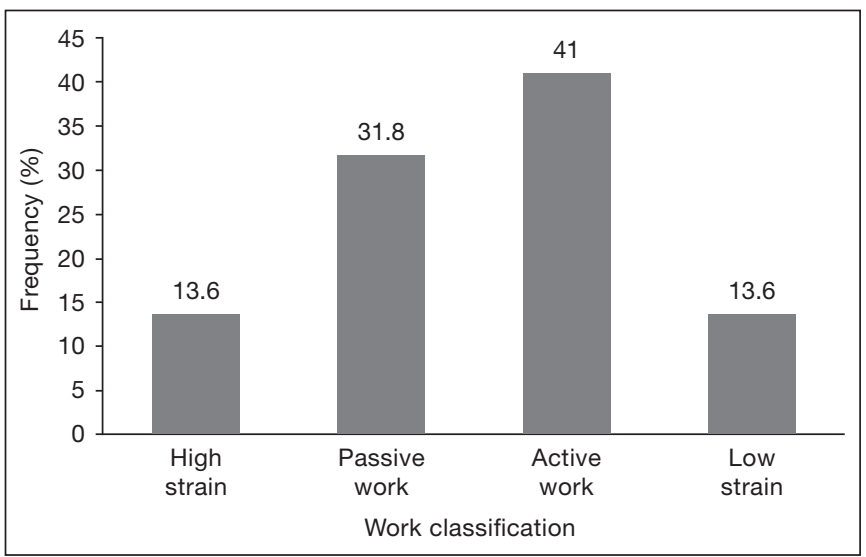

Figure 2. Frequencies of musicians according to demand-control model quadrants to intellectual judgment and $72.7 \%$ of musicians have perceived high control in the dimension authority over decisions. All musicians (100\%) have perceived major social support at work. Medians of work-related stress were: demand=14, control $=20$ and social support $=21$.

Specific analysis of each question of the work-related stress scale has shown that, considering demand, the question "does your work usually have contradictory or conflicting requirements?" had the worst evaluation and the question "Do you have enough time to perform all the tasks of your work?" had the most positive perception. In the dimension control, questions with more negative perception were: "Can you choose how to perform your work?" and "Can you choose what to do in your work?" In the dimension social support, questions "There is a relaxed and pleasant environment where I work" and "If I am not in a good day my colleagues understand" were those with more negative perceptions.

By allocating musculoskeletal complaints frequencies to the demand and control quadrants (Table 2) it was possible to observe that more severe complaints were, in first place, from musicians with perception of high strain, followed by those with perception of active work. Considering workers with perception of high strain at work, regions with more frequent complaints were neck, left shoulder, left arm, left wrist, paravertebral region and lumbar region.

Table 2. Prevalence of musculoskeletal complaints according to demand-control quadrants

\begin{tabular}{lcccc}
\hline Musculoskeletal & \multicolumn{4}{c}{ Work classification (\%) } \\
complaints & $\begin{array}{c}\text { High } \\
\text { strain }\end{array}$ & $\begin{array}{c}\text { Passive } \\
\text { work }\end{array}$ & $\begin{array}{c}\text { Active } \\
\text { work }\end{array}$ & $\begin{array}{c}\text { Low } \\
\text { strain }\end{array}$ \\
\hline Neck & 66.7 & 42.9 & 66.7 & 33.3 \\
Left shoulder & 66.7 & 42.9 & 55.6 & 33.3 \\
Right shoulder & 33.3 & 14.3 & 22.2 & 33.3 \\
Left arm & 66.7 & 28.6 & 22.2 & 33.3 \\
Right arm & 33.3 & 14.3 & 11.1 & 0 \\
Left elbow & 33.3 & 0 & 12.5 & 0 \\
Right elbow & 33.3 & 0 & 12.5 & 0 \\
Left forearm & 33.3 & 0 & 22.2 & 33.3 \\
Right forearm & 0 & 16.7 & 28.6 & 0 \\
Left wrist & 66.7 & 42.9 & 33.3 & 0 \\
Right wrist & 33.3 & 28.6 & 22.2 & 0 \\
Left hand & 33.3 & 28.6 & 33.3 & 33.3 \\
Right hand & 33.3 & 28.6 & 22.2 & 33.3 \\
Upper back & 33.3 & 42.9 & 55.6 & 0 \\
Paravertebral region & 66.7 & 0 & 44.4 & 0 \\
Lumbar region & 66.7 & 0 & 33.3 & 33.3 \\
\hline
\end{tabular}

The factorial analysis for major components has extracted six factors with self-scores above 1 . These factors were responsible for $13.73 \%$ of total explained variance. Grouped questions and their respective domains are shown in table 3. Factor 3, responsible for the highest isolated explanation percentage, was made up of three control and one demand questions. All social support questions were grouped. Demand question 
Table 3. Distribution of motivation evaluation questions according to grouping factors

\begin{tabular}{|c|c|c|c|c|}
\hline Factors & Questions & Domains & $\mathrm{p}$ & Explanation (\%) \\
\hline \multirow{2}{*}{1} & How often do you have to perform your working tasks very fast? & Demand & 0.8604 & \multirow{2}{*}{2.16} \\
\hline & Does your work require too much from you? & Demand & 0.8064 & \\
\hline \multirow{2}{*}{2} & At work we have good relations with each other. & Social support & 0.7545 & \multirow{2}{*}{2.44} \\
\hline & I enjoy working with my colleagues. & Social support & 0.8852 & \\
\hline \multirow{2}{*}{3} & Do you have enough time to perform all tasks of your work? & Demand & 0.8110 & \multirow{2}{*}{1.82} \\
\hline & There is a relaxed and pleasant environment where I work. & Social support & 0.7497 & \\
\hline 4 & At work, I have good relations with my bosses. & Social support & 0.7071 & 1.92 \\
\hline \multirow{4}{*}{5} & How often do you have to work hard (that is, producing too much too soon)? & Demand & 0.8384 & \multirow{4}{*}{3.49} \\
\hline & Does your work require lots of skills or specialized knowledge? & Control & 0.8530 & \\
\hline & Does you work require you to take initiatives? & Control & 0.7290 & \\
\hline & Can you choose what to do at work? & Control & 0.8315 & \\
\hline 6 & Do you have chance of learning new things at work? & Control & 0.7819 & 1.90 \\
\hline
\end{tabular}

"Does your work usually have contradictory or conflictin requirements?" and control question "Can you choose how to perform your work?" were not grouped in factors.

\section{DISCUSSION}

This study has shown some trends of associations between musculoskeletal complaints and work-related stress among orchestra musicians. Considering the demand-control model, most musicians had perception of active work. This type of work, according to Karasek and Theorell ${ }^{11}$, poses high psychological demands; however, it allows workers to have a broad possibility of decision about how and when to develop their tasks, as well as using their total intellectual potential to do so, providing growth and learning.

In case of the studied orchestra, this perception might have also been influenced by the major positive perception of social support shown by musicians, which may importantly cooperate for workers' health. So, it is inferred that this labor activity allows its professionals to have creative autonomy in their presentations, including, for example, the selection of classic or modern pieces, standing out the support of colleagues for such decisions. These trends are to be confirmed by further studies with different orchestras, to get the general scenario of such professional activity.

Active work, although being a positive situation, may also, as observed with professors ${ }^{23}$, trigger more personal demands and higher indices of mental tiredness, jitters and poorer quality of life. So, although musicians have in general presented a positive perception of their work, interventions in situations with negative perceptions of the studied group, for example, the existence of contradictory tasks and lack of control on how and what to do with regard to proposed tasks, may contribute to improve working conditions of such professionals. High cognitive demands are typical and present in the activities of professional musicians and have already been observed by other studies ${ }^{4,24,25}$ being also associated to characteristics of the profession which requires accurate per- formance obtained by means of long training periods and high concentration demands. Our results had trends similar to the study with Turkish musicians ${ }^{7}$ which has observed more body discomforts among musicians with perception of higher demand and lower control. In addition to exhausting trainings, an important demand aspect is the little time orchestra musicians have to master several songs for a certain presentation. However, although the $s \mathrm{udy}^{7}$ has not presented the classification of demand and control quadrants, Brazilian musicians, in general, had a more positive perception of work-related stress.

High frequencies of musculoskeletal complaints referred by musicians confirm literature data ${ }^{3,4,26}$, by indicating that this is a profession which may lead to major physical stress and even to medical leave. A study by Araújo and Cardia ${ }^{25}$ discusses that muscle tension and discomfort among musicians are caused by wrong posture when playing the instrument, by postural inadequacies caused by the inadequacy of instrument accessories size, by technical execution vices without major postural repercussions, but which cause excessive muscle tension or contraction with joint or neuromuscular overload and muscle and joint diseases.

In addition, musicians according to Frank and Mühlen ${ }^{27}$, normally do not look for health professionals assistance in the presence of physical warning signs, with fear of losing professional space and decreasing financial gains which leads to the worsening of the clinical presentation, which starts with minor discomfort and may progress to diseases leading to withdrawal from employment. Educative ergonomic measures to improve musicians' work are indicated in the study ${ }^{3}$ as a possibility of intervention, in addition to better public policies for this professional category, which sometimes may work informally.

\section{CONCLUSION}

In general, results have evidenced body regions with higher frequencies of complaints, which should be primarily assisted 
by ergonomic measures. With regard to work-related stress, questions which may be focus of interventions are those allocated to the factor with the highest stress explanation, that is, the frequency of hard work in little time, need for specialized knowledge, need to take initiatives and possibility of choosing what to do at work.

\section{REFERENCES}

1. Larsson LG, Baum J, Mudholkar GS, Kollia GD. Nature and impact of musculoskeletal problems in a population of musicians. Med Probl Perform Art. 1993;8(3):73-6.

2. Steinmetz A, Seidel W, Niemier K. Shoulder pain and holding position of the violin. Med Probl Perform Art. 2008;2(23):79-81.

3. Teixeira CS, Kothe F, Pereira EF, Mota CB. Características cinéticas durante a marcha de um músico com e sem o transporte de seu instrumento. Rev Bras Cineantropom Desempenho Humano. 2009;11(1):43-50.

4. Teixeira CS, Kothe F, Pereira EF, Lopes LF, Merino EA. Superuso musculoesquelético e fatores associados em músicos de orquestra. Motriz. 2010;16(1):17-27.

5. Hamilton LH, Kella J, Hamilton WG. Personality and occupational stress in elite performers. Med Probl Perform Art. 1995;10(1):86-9.

6. Kähäri K, Zachau G, Eklöf M, Möller C. The influence of music and stress on musicians' hearing. J Sound and Vibr. 2004;277(3):627-31.

7. Akel S, Düger T. Psychosocial risk factors of musicians in Turkey. Med Probl Perform Art. 2007;22(4):147-52.

8. Brown DL, Zahuranec DB, Majersik JJ, Wren PA, Gruis KL, Zupancic M, et al. Risk of sleep apnea in orchestra members. Sleep Med. 2009;10(6):657-60.

9. Pereira EF, Teixeira CS, Kothe F, Merino EA, Daronco LS. Percepção de qualidade do sono e da qualidade de vida de músicos de orquestra. Rev Psiquiatr Clín. 2010;37(2):48-51.

10. Alves MG, Hokerberg YH, Faerstein E. Trends and diversity in the empirical use of Karasek's demand-control model (job strain): a systematic review. Rev Bras Epidemiol. 2013;16(1):125-36. Portuguese.

11. Karasek RA, Theorell T. Healthy work-stress, productivity, and the reconstruction of working life. New York: Basic Books; 1990.

12. Theorell T, Karasek RA. Current issues relating to psychosocial job strain and cardiovascular disease research. J Occup Health Psychol. 1996;1(1):9-26.
13. Urbanetto Jde S, Magalhães MC, Maciel VO, Sant'Anna VM, Gustavo Ada S, Poli-de-Figueiredo CE, et al. [Work-related stress according to the Demand-Control Model and Minor Psychic Disorder in nursing workers]. Rev Esc Enferm USP. 2013;47(5):1186-93. Portuguese.

14. Ferreira DK, Bonfim C, Augusto LG. Condiçốes de trabalho e morbidade referida de policiais militares, Recife-PE, Brasil. Saúde Soc. 2012;21(4):989-1000.

15. Silva LS, Barreto SM. [Stressful working conditions and poor self-rated health among financial services employees]. Rev Saude Publica. 2012; 46(3):407-16. Portuguese.

16. Cardoso JP, Araújo TM, Carvalho FM, Oliveira NF, Reis EJ. [Psychosocial work-related factors and musculoskeletal pain among schoolteachers]. Cad Saude Publica. 2011;27(8):1498-506. Portuguese.

17. Kourinka I, Jonsson B, Kilbom Å, Vinterberg H, Biering-Sorensen F, Andersson G, et al. Standardized Nordic questionnaire for the analysis of musculoskeletal symptoms. Appl Ergon. 1987;18(3):223-37.

18. Engquist K, Orbaek P, Jakobsson K. Musculoskeletal pain and impact on performance in orchestra musicians and actors. Med Probl Perform Art. 2004;19(2):55-61.

19. de Barros EN, Alexandre NM. Cross-cultural adaptation of the Nordic musculoskeletal questionnaire. Int Nurs Rev. 2003;50(2):101-8.

20. Pinheiro FA, Troccoli BT, Carvalho CV. [Validity of the Nordic Musculoskeletal Questionnaire as morbidity measurement tool]. Rev Saude Publica. 2002;36(3):30712. Portuguese.

21. Corlett EN, Manenica I. The effects and measurement of working postures. App Ergon. 1980;11(1):7-16.

22. Alves MG, Chor D, Faerstein E, Lopes Cde S, Werneck GL. [Short version of the "job stress scale" a Portuguese-language adaptation]. Rev Saude Publica. 2004;38(2):16471. Portuguese.

23. Reis EJ, Araújo TM, Carvalho FM, Barbalho L, Silva M. Docência e exaustão emocional. Educ Soc. 2006;27(94):229-53

24. Lederman RJ. Neuromuscular and musculoskeletal problems in instrumental musicians. Muscle Nerve. 2003;27(5):549-61.

25. Araújo NC, Cardia MC. A presença de vícios posturais durante a execuçăo do violino. Anais Congresso Brasileiro de Biomecânica; 18-22 de junho 2005; João Pessoa, Brasil. Joâo Pessoa: Sociedade Brasileira de Biomecânica; 2005.

26. Petrus AM, Echternacht EH. O. Dois violinistas e uma orquestra: diversidade operatória e desgaste músculo-esquelético. Rev Bras Saúde Ocup. 2004;29(109):31-6.

27. Frank A, Mühlen CA. Queixas musculoesqueléticas em músicos: prevalência e fatores de risco. Rev Bras Reumatol. 2007;47(3):188-90. 